${ }^{*}$ Doc. dr. sc. Domagoj Runje, Katolički bogoslovni fakultet Sveučilišta u Splitu, Zrinsko-frankopanska 19, 21000 Split, Hrvatska, drunje2@kbf-st.hr

\title{
Odnos Barzilaja Gileađanina prema vlastitoj starosti
}

\author{
Domagoj RUNJE* \\ • https://doi.org/10.31823/d.26.3.4 • UDK: 27-243.35 • Pregledni članak \\ Primljeno: 7. prosinca 2017. • Prihvaćeno: 17. rujna 2018.
}

Sažetak: Lik Barzilaja Gileađanina pojavljuje se više puta u biblijskim tekstovima od kojih su najvažniji 2 Sam 17, 2729 gdje Barzilaj pomaže kralju Davidu u bijegu pred pobunjenim sinom Abšalomom i 2 Sam 19, 32-40 gdje se Barzilaj drugi put susreće s kraljem Davidom i govori o svojoj starosti. U ovom izlaganju to je središnji tekst na temelju kojega se promatra Barzilajev odnos prema vlastitoj starosti. Uz to navodi se i nekoliko tekstova iz židovske izvanbiblijske tradicije koji pomažu boljem razumijevanju toga biblijskoga lika.

Ključne riječi: Barzilaj, kralj David, starost, Biblija, Talmud.

\section{Uvod}

U Bibliji postoji više likova s različitim iskustvima u staračkoj dobi. Nekima od njih staračka dob najvažnije je i najdetaljnije opisano životno razdoblje. Abraham i Sara tek u staračkoj dobi dobivaju sina Izaka. Njemu je bilo stotinu, a njoj devedeset godina (Post 17, 17). Na kraju je Sara umrla sa stotinu dvadeset i sedam godina (Post 23, 1), a Abraham $\gg$ (...) umrije u sretnoj dobi - star i pun godina - te bi pridružen svojim precima $\ll($ Post 25,8$)$.

Mojsija u osamdesetoj godini Bog poziva da izvede narod iz egipatskoga ropstva ( $\mathrm{Izl} 7,7)$, a sa sto dvadeset godina umire po Božjoj zapovijedi s napomenom da je bio u punoj životnoj snazi (Pnz 34, 7).

I drugi veliki likovi doživjeli su sretnu starost nauživši se života. Abrahamov sin Izak, premda je u starosti patio zbog sljepoće, umro je sretno kao »starac i godinama zasićen « (Post 35, 29). I Izakov sin Jakov, iako se pomalo patetično 
izražava pred faraonom govoreći o svome nesretnom, lutalačkom i kratkotrajnom životu (Post 47, 9), zapravo je doživio lijepu starost i umro u dobi od sto trideset godina, nakon što je blagoslovio sve svoje sinove (Post 49, 33).

Postoje, naravno, i biblijski tekstovi koji stavljaju u prvi plan kratkotrajnost i muku ljudskoga vijeka kao često citirani Psalam 90:

>Zbroj naše dobi sedamdeset je godina, ako smo snažni, i osamdeset; a većina od njih muka je i ništavost: jer prolaze brzo i mi letimo odavle.« (Ps 90, 10)

Biblijski Propovjednik veoma slikovito tuži se na staračke tegobe i ovako ih opisuje:

$\gg$ Kad je put uzbrdo muka i svaki izlazak prijetnja; a badem je u cvatu, i skakavac ne skače više, i koprov plod puca, jer čovjek ide u svoj vječni dom! A narikače već se kreću ulicama.« (Prop 12,5)

Starost je dob dostojna posebnoga poštovanja, ali ima i tekstova koji govore kako visoki broj godina nije po sebi znak moralne i duhovne zrelosti (npr.Job 32, 9; Mudr 4, 8-9.16; Dn 13, 1-64). Ipak, premda s godinama ljudske moralne slabosti same od sebe ne nestaju, biblijski tekstovi i Staroga i Novoga zavjeta jednodušno nalažu poštovanje prema osobama starije dobi (npr. Lev 19, 32; Sir 8, 6; 1 Tim 5, 1-2).

Od mnoštva biblijskih likova o čijoj bi se starosti moglo govoriti u ovom smo izlaganju kao biblijski primjer odnosa prema starosti i starenju izabrali lik Barzilaja Gileađanina kojega prvi put susrećemo u 2 Sam 17, 27-29. Razlog zbog kojega baš njega ovdje želimo predstaviti jest taj što u 2 Sam 19, 32-40 nalazimo opis susreta Barzilaja s kraljem Davidom, u kojem Barzilaj dojmljivo govori o svojoj starosti. Taj Barzilajev govor središnji je tekst kojim ćemo se ovdje pozabaviti, ali ćemo spomenuti i ostale biblijske tekstove u kojima se spominje taj lik. Na koncu promotrit ćemo taj lik i kroz zrcalo nekoliko primjera izvanbiblijske tradicije koji nam pomažu u boljem razumijevanju Barzilajeva odnosa prema vlastitoj starosti i životu uopće.

\section{Prvi spomen Barzilaja Gileađanina u 2 Sam 17, 27-29}

Lik Barzilaja ${ }^{1}$ Gileađanina prvi put susrećemo u 2 Sam 17, 27-29. Kontekst je Davidov bijeg pred sinom Abšalomom koji se proglasio kraljem $u$ Jeruzalemu i pridobio za sebe naklonost većine naroda. Riječ je o kriznoj situaciji ne samo na političkoj nego i na obiteljskoj i osobnoj razini. Složena kraljeva obitelj u kojoj ima više žena i djece iz različitih veza plodno je tlo za međusobne nesuglasice i trvenja, a kralj David nije na vrijeme i prikladno rješavao probleme među članovima svoje mnogobrojne obitelji. Uz to sam je počinio preljub s Bat Šebom, ženom Urije Hetita, a kad je ona u preljubu ostala trudna, htio je dijete podmetnuti njezinu mužu. Kad

\footnotetext{
${ }^{1}$ Ime Barzilaj dolazi od hebrejske riječi barzel što znači željezo. Gilead je područje istočno od Jordana.
} 
mu to nije uspjelo, organizirao je ubojstvo Urije Hetita, a s Bat Šebom se oženio. David nije prikladno i pravovremeno reagirao ni kad je njegov sin Amnom silovao svoju polusestru, a pravu Abšalomovu sestru Tamaru. Sve to može se tumačiti kao razlog zbog kojega je došlo do Abšalomove pobune. ${ }^{2}$ Stanje u tom slučaju još je dramatičnije zato što David veoma voli svoga sina Abšaloma, a život ih je doveo u sukob u koji je uključen cijeli narod trenutačno podijeljen na većinu koja je stala uz Abšaloma i manjinu Davidu lojalnih ljudi. Sukob će završiti Davidovim povratkom na prijestolje nakon bizarnog Abšalomova stradanja kad mu je glava s dugom kosom zapela o granu stabla. Davidovo oplakivanje Abšaloma daje cijelom događaju još tužniju notu jer se sukob oca i voljenoga sina završio s neriješenim računima.

U tom političkom i obiteljskom kontekstu, dok je David sa svojim ljudima još bio u bijegu i tako došao u Mahanajim, spominju se trojica lojalnih građana koji su stali na njegovu stranu i pomogli mu svojim sredstvima. To su $\gg$ Šobi, sin Nahašev iz Rabe Amonske, pa Makir, sin Amielov iz Lo Debara, i Barzilaj, Gileađanin iz Rogelima $\ll$ (2 Sam 17, 27).

Kasnije, nakon Abšalomova stradanja koje je Davidu otvorilo slobodan put za povratak u Jeruzalem, Šobi i Makir više se ne spominju, a Barzilaj Gileađanin dolazi u susret kralju Davidu da ga isprati preko Jordana.

U tom susretu odvija se razgovor Davida i Barzilaja u kojem ovaj govori o svojoj starosti.

\section{Barzilajev susret s Davidom u 2 Sam 19, 32-40}

Na povratku u Jeruzalem nakon Abšalomova poraza Davida prati mnoštvo ljudi. Među njima ističe se Barzilaj Gileađanin. Prije nego što se on pridružio Davidovoj pratnji susreo se David sa Šimejom Benjaminovcem i Meriabaalom, koji se u 2 Sam 19, 25 naziva sinom Šaulovim, a zapravo mu je unuk, sin Jonatanov. Šimej je prethodno proklinjao Davida (2 Sam 16, 5-7), a hromi Meribaal nije u vrijeme Abšalomove pobune pošao iz Jeruzalema za Davidom. Šimej traži oproštenje zbog teških riječi koje je rekao, a Meribaal se opravdava da nije pošao za Davidom zato što mu sluga Siba nije htio pripremiti magarca (2 Sam 19, 27-28). David i jednomu i drugomu zasada iskazuje milost. Kasnije će Davidov nasljednik Salomon smaknuti Šimeja (1 Kr 2, 36-46), a pri smaknuću članova Šaulova doma Meribaal će ipak biti pošteđen zbog zakletve koju je David dao njegovu ocu Jonatanu (usp. 2 Sam 21, 7; 1 Sam 24, 22-23).

Kad nakon te dvojice Davidu pristupa Barzilaj, pred njim je čovjek koji ga je zadužio svojom odanošću. Za vrijeme Abašlomove pobune Barzilaj je otvoreno stao

\footnotetext{
${ }^{2}$ Usp. A. POPOVIĆ, Povijesne knjige, Zagreb, 2015., 136.
} 
na Davidovu stranu i ostao mu vjeran u teškim trenutcima. Ta lojalnost vidi se i u ovom susretu gdje se Barzilaj obraća Davidu i upadno ga stalno naziva kraljem. Stoga, dok je Šimeju i Meribaalu iskazao milost opraštanjem, David osjeća da Barzilaja treba nagraditi.

Na temelju toga što je u vrijeme potrebe opskrbljivao Davida i njegove ljude već smo znali da je Barzilaj bio imućan čovjek. Sada je to izričito rečeno, ${ }^{3}$ a uz to doznajemo i da je star. Osamdeset mu je godina. David se želi odužiti Barzilaju time što ga poziva na svoj dvor gdje će ga uzdržavati do smrti (2 Sam 19, 34). Davidova je nagrada plemenita, ali ne odgovora Barzilajevim željama i potrebama. Kao veoma staru čovjeku Barzilaju ne predstoji mnogo godina života, a zbog starosti ne može ni uživati sve blagodati života na kraljevskom dvoru. Barzilajev odgovor Davidu, uz tvrdnju da mu je sada osamdeset godina, satkan je od niza retoričkih pitanja kojima opisuje svoju staračku dob te završava molbom u kojoj izriče svoje posljednje želje. U nastavku ćemo prokomentirati pojedine rečenice Barzilajeva odgovora u 2 Sam 19, 35-38 koji radi lakšega praćenja ovdje donosimo u cijelosti. ${ }^{4}$ Podijelili smo ga na dva dijela. ${ }^{5}$ Prvi donosi opis staračke dobi, a u drugom su Barzilajeve želje:

Barzilajev opis vlastite staračke dobi (2 Sam 19, 35-36)

$\gg$ A koliko mi još godina života ostaje da idem $\mathrm{s}$ kraljem u Jeruzalem?

Sada mi je osamdeset godina;

Mogu li razlikovati između dobra i zla?

Može li tvojem sluzi goditi što jede i pije?

Mogu li još slušati glas pjevača i pjevačica?«

Barzilajeve posljednje želje (2 Sam 19, 37-38)

Zašto bi tvoj sluga bio još na teret mome gospodaru kralju?

Tvoj će sluga još samo prijeći preko Jordana s kraljem, ali zašto bi mi kralj dao takvu nagradu?

Dopusti svome sluzi da se vrati, da umrem u svom gradu kod groba svoga oca $i$ svoje majke.

Ali evo tvoga sluge Kimhama, neka ide dalje s mojim gospodarom kraljem, pa njemu učini što je dobro u tvojim očima!

\footnotetext{
${ }^{3}$ Izvorni je izraz 'î̌s gädôl - velik čovjek, a odnosi se na visoki društveni i materijalni status.

${ }^{4} \mathrm{U}$ ovom radu koristili smo se hrvatskim prijevodom Biblije u izdanju Kršćanske sadašnjosti koji je dostupan u programu Bible Works version 10.0.5559. Ipak, Barzilajev odgovor Davidu u 2 Sam 19, 37-38 ponešto smo izmijenili tako da smo nastojali da prijevod bude što doslovniji.

${ }_{5}^{5}$ Ta podjela nije rezultat retoričke analize, nego je sadržaj Barzilajeva govora podijeljen na dvije bitne sastavnice.
} 


\subsection{BARZILAJEV OPIS VLASTITE STARAČKE DOBI}

Retoričkim pitanjem: »A koliko mi još godina života ostaje da idem $\mathrm{s}$ kraljem u Jeruzalem? « i izjavom: »sada mi je osamdeset godina «, Barzilaj izražava svijest da pred sobom nema mnogo godina života. Isto tako on ne želi ostatak života provesti ignorirajući svoju dob koja se približila prirodnoj smrti. Sljedećim trima retoričkim pitanjima Barzilaj istodobno opisuje svoje životno stanje i stil života na kraljevskom dvoru koji smatra neprikladnim za čovjeka njegove dobi.

Pitanje: »Mogu li razlikovati između dobra i zla? « koje izgovara osamdesetogodišnjak razumijemo u smislu da je u mlađoj dobi Barzilaj mogao razlikovati dobro i zlo, a sada to ne može. ${ }^{6}$ Doslovno značenje izraza razlikovati izmedu dobra i zla upućuje na sposobnost intelektualnoga i moralnoga rasuđivanja. U tom smislu, govoreći o svojoj nesposobnosti razlikovanja između dobra i zla, Barzilaj bi se predstavio kao starac koji je podjetinjio. Ali takvo značenje u ovom slučaju treba isključiti jer u svom odgovoru kralju Davidu Barzilaj se baš pokazuje mudrim čovjekom koji pametno rasuđuje.

Prije će biti da se starac Barzilaj vratio na djetinju dob u jednom drugom smislu. Jacob Milgrom u svome opsežnom komentaru knjige Levitskoga zakonika navodi upravo 2 Sam 19, 36 kao jedan od dvaju sigurnih primjera u kojima se izraz razlikovati dobro i zlo odnosi na spolnu aktivnost. ${ }^{7}$ Drugi Milgromov primjer jest Pnz 1, 39 gdje se izraz »sinovi vaši koji još ne znaju razlikovati dobro i zlo « odnosi na spolno nezrelu djecu. Sličan izraz u značenju spolne nezrelosti nalazimo i u Iz 7, 15-16 gdje se govori o Emanuelu: $\gg$ Vrhnjem i medom on će se hraniti dok ne nauči odbacivat' zlo i birati dobro. Jer prije nego dječak nauči odbacivat' zlo i birati dobro, opustjet će zemlja, zbog koje strepiš, od dvaju kraljeva.« Ako se naviješteni Emanuel odnosi na Ezekiju, sina kralja Ahaza, koji se rodio nakon navedenoga Izaijina proroštva, imamo znakovitu kronološku podudarnost. Siro-efrajimski rat izbio je kad je Ezekiji bilo oko dvanaest godina, tj. na pragu puberteta, odnosno spolnoga sazrijevanja. ${ }^{8}$

\footnotetext{
${ }^{6}$ U prijevodu Kršćanske sadašnjosti ta rečenica glasi: »Mogu li još razlikovati što je dobro a što zlo? « (2 Sam 19, 36). Prilog još koji smo istaknuli dobro izražava misao da je Barzilaj iz stanja u kojem je mogao razlikovati dobro i zlo prešao u stanje kada to ne može. Priloga još ipak nema u masoretskom tekstu, pa smo ga izostavili.

${ }^{7}$ Usp. J. MILGROM, Leviticus 17 - 22, Anchor Bible 3a, Doubleday, 2000., 1502.

${ }^{8}$ Usp. R. GORDIS, The Knowledge of Good and Evil in the Old Testament and the Qumran Scrolls, u: Journal of Biblical Literature 76(1957.)2, 136.; Služili smo se elektroničkim izdanjem toga članka koji se može naći na mrežnoj stranici: http://www.jstor.org/stable/3261283 (20. 11. 2017.). Kako smo već spomenuli, prema Jacobu Milgromu, stablo spoznaje dobra i zla u Post 2, 17 također je povezano s temom spolnosti. Usp. J. MILGROM, Leviticus 17 - 22, 1502. Kontekst u opisu stvaranja muškarca i žene te njihovu prvom grijehu u Post $2-3$ dosta je složen. Adam i Eva predstavljeni su kao odrasle, ali mlade osobe. Ipak, ne govori se ništa izričito o njihovu spolnom odnosu prije
} 
Prema tomu Barzilaj bi kao razlog zbog kojega se zahvaljuje na Davidovoj ponudi naveo svoju spolnu nemoć uzrokovanu starošću. Zbog toga on ne može uživati u svemu što se nudi na kraljevskom dvoru, a to je prema praksi onoga vremena uključivalo i žene priležnice (usp. 2 Sam 3, 8). Ne možemo znati s kakvom je intonacijom Barzilaj izrekao te riječi, ali cilj njegova odgovora čini se kao da ne stavlja u prvi plan žaljenje za proteklim vremenima. Takvo stanje, kao i ostalo što će navesti, služi mu za opravdanje odbijanja Davidove velikodušne ponude te očekuje da će to kralj primiti s razumijevanjem. Barzilaj se pokazuje kao čovjek koji je svjestan da sve ima svoje vrijeme te da s osamdeset godina ne može živjeti kao da mu je dvadeset.

Pitanje Može li tvojem sluzi goditi što jede i pije? nadovezuje se na opis onoga što bi Barzilaja čekalo na kraljevskom dvoru. Među ostalim to su i gozbe u kojima se jedu birana i slasna jela. Barzilajevu nemogućnost da uživa u jelu i piću možemo razumjeti $\mathrm{u}$ širem kontekstu zdravstvenih problema. U starijoj dobi čovjek ima više problema s probavom, a dolaze i različite bolesti zbog kojih mu mnoga hrana i piće škodi.

Treće retoričko pitanje Mogu li još slušati glas pjevača i pjevačica? možda se odnosi na Barzilajev oslabljen sluh, zbog čega više ne može uživati u glazbi. Ali vjerojatno je riječ jednostavno o tome da Barzilaj više nema volje za zabavu. Pjevači i pjevačice jedan su od simbola raskošnoga dvorskoga života (usp. Prop 2, 8), ali Barzilaj više ne može uživati u onome u čemu bi sigurno uživao da je mlađi.

Prema tomu, sva tri navedena retorička pitanja imaju isto značenje koje možemo zgodno ilustrirati zanimljivom bilješkom iz jednoga staroga hrvatskoga prijevoda Biblije. Naime u svom prijevodu Svetoga pisma iz 1858. godine Ivan Matija Škarić u bilješci uz 2 Sam 19, 35 ovako prepričava Barzilajev odgovor Davidu:

$\gg$ Ja-sam jurve ostario, govori Berzelai, i otupila-su sva moja ćutila. Da-bih dakle ja došao $s$ tobom u tvoju polaču, ne-bih bio u stanju uzćutiti ikakve od onih ugodnostih, koje dvorani uživaju u kraljevoj polači, a bio-bih-ti dosadan, jer staro čeljade nemože da nedodija onim, koji -su s njim. Hvala-ti dakle na priateljstvu, kojega ja neimam primiti. ${ }^{9}$

izgona iz raja. To je izričito spomenuto tek u Post 4, 1: »Čovjek pozna svoju ženu Evu, a ona zače i rodi Kajina ... « Usp. A. POPOVIĆ, Stvaranje čovjeka i izgon iz zemaljskog raja (Post 2, 4 - 3, 24). Starije (dijakronijsko) i novije (sinkronijsko) tumačenje biblijskog teksta, u: Bogoslovska smotra 86(2016.)1, 91-113., ovdje 105.

${ }^{9}$ I. M. ŠKARIĆ, Sveto pismo Staroga i Novoga uvita iz latinskoga s obzirom na matične knjige izbistreno $i$ iztumačeno, III, Beč, 1858., 222.; Za bolje poznavanje Škarićeva prijevoda upućujemo na članak M. VIDOVIĆ, Škarićevo Sveto pismo. Izuzetnost pothvata i neka rješenja u uvodima i komentarima, u: Crkva u svijetu 38(2003.)4, 501-530. 
Možemo samo zaključiti kako je Škarićevo jednostavno i razumljivo shvaćanje Barzilajeva ljubaznoga odbijanja Davidove nagrade s obzirom na odnos prema starijim osobama aktualno i danas. U nastavku će navedena Škarićeva bilješka biti potvrđena Barzilajevim željama.

\subsection{BARZILAJEVE POSLJEDNJE ŽELJE}

Nakon opisa svoje staračke dobi Barzilaj izražava svoje želje. Nazivajući se kraljevim slugom, on te želje izražava u obliku molbe.

Prva Barzilajeva želja i molba jest da kralju ne bude na teret. David je ponudio Barzilaju da pođe s njim u Jeruzalem gdje će ga uzdržavati u starim danima. No Barzilaju to nije potrebno. On je imućan čovjek. Stoga se njegov osjećaj da će biti kralju na teret vjerojatno ne odnosi na troškove materijalnoga uzdržavanja. Prije će biti riječ o tome da Barzilaj ne želi biti na teret u već spomenutom smislu. Stari Barzilaj više ne može uživati u blagodatima života na kraljevskom dvoru i teško bi se uklopio u društvo kralja Davida i njegovih prijatelja koji su još u punoj životnoj snazi. Smetao bi im.

Ali moguće je i da su razlozi Barzilajeva odbijanja Davidove nagrade dublji. David u svojoj ponudi, svjesno ili nesvjesno, Barzilaja dovodi u položaj podređenosti i ovisnosti što on nije mogao prihvatiti. Barzilaj, doduše, Davida stalno naziva kraljem, a sebe njegovim slugom, ali takvo protokolarno obraćanje ne može sakriti ono što i jedan i drugi osjećaju. Kad je Barzilaj Davidu pomagao u bijegu pred Abšalomom, on je, uz to što je zbog svoje imućnosti već bio na visokoj društvenoj ljestvici u svojoj sredini, morao imati i dodatni osjećaj superiornosti. Kao onaj koji pomaže, Barzilaj je u tom trenutku bio moćniji od Davida kojemu je bila potrebna pomoć. Čini se stoga kao da je David, kada je htio nagraditi Barzilaja, ispustio iz vida njegov ponos. Ili ga je možda namjerno htio 'prizemljiti'?

Budući da je Barzilaj materijalno pomagao Davidu kad mu je to bilo potrebno, s jedne strane možemo razumjeti da mu David sada želi uzvratiti na isti način. Tako se David ne bi Barzilaju osjećao ništa dužan. Međutim možda je Barzilaj za uzvrat očekivao nešto drugo. Barzilajev odgovor Davidu bio bi sigurno drukčiji da ga je David pozvao na svoj dvor, da mu kao iskusni i mudri starac bude savjetnikom. U tom slučaju Barzilaj se ne bi osjećao teretom, nego bi doživio valorizaciju primjerenu čovjeku njegove dobi. Budući da se to nije dogodilo, on se na elegantan način povlači. Tako njegovo odbijanje Davidove nagrade postaje još jedan njegov častan čin, premda njegove riječi »zašto bi mi kralj dao takvu nagradu « u kontekstu njegovih staračkih slabosti zvuče tugaljivo i razočarano. Kralj mu je naime mogao dati neku drugu primjereniju nagradu. 
S druge strane taj susret s Davidom otvorio je Barzilaju oči za vrijednosti koje može ostvariti u malom broju godina koje su mu još preostale do smrti. Budući da ga kralj David ne poziva da mu na dvoru bude od koristi, a nagradu koju mu želi dati ne može iskoristiti, Barzilaj se okreće svojoj kući. Ondje može živjeti neovisno o kralju i u prvi plan staviti rješavanje odnosa s članovima svoje obitelji.

O Barzilajevoj obitelji ne znamo mnogo, a o njegovu prijašnjem životu možemo samo nagađati.

Znamo da su Barzilajevi roditelji umrli i da su pokopani u njegovu gradu, pa i on želi uz njih umrijeti. U toj želji Barzilaj još jednom izražava svijest o blizini smrti. No želja da umre uz grob svoga oca i majke sugerira kako je ovdje riječ i o Barzilajevoj potrebi da uredi svoje odnose s pokojnim roditeljima. Budući da u Bibliji nemamo nikakav izričit podatak o Barzilajevu odnosu prema roditeljima, ono što možemo pretpostaviti temelji se isključivo na izrazu umrijeti u svom gradu kod groba oca i majke.

Postoji više biblijskih primjera iz doba patrijarha u kojima se na grobu napokon sređuju zapleteni odnosi među članovima obitelji. Tako je nakon mnogih dramatičnih životnih epizoda Abraham pokopan u grob sa svojom ženom Sarom, a sahranili su ga zajedno njegovi sinovi Izak i Jišmael, koji inače nisu uživali isti status u Abrahamovoj obitelji (Post 25, 8-10). ${ }^{10}$

U istu grobnicu u špilji na polju Makpeli gdje je prethodno pokopao svoju nevoljenu ženu Leu bit će, prema svojoj izričitoj želji, pokopan i Jakov (Post 49, 31). Prema $\mathrm{Dj} 7,13 \mathrm{u}$ istu grobnicu pokopan je i Josip i sva njegova braća, pa je to zajedničko počivalište postalo mjestom konačno sređenih obiteljskih odnosa.

Ako u tom smislu shvatimo i Barzilajevu želju da umre uz grob svojih roditelja, onda je ovdje riječ o čovjeku koji želi otići s ovoga svijeta sa što je moguće bolje uređenim odnosima i prema mrtvim i prema živim članovima svoje obitelji.

Na to se nadovezuje sljedeća Barzilajeva molba. On moli Davida da nagradu koju je namjeravao dati njemu dade svome sluzi Kimhamu. Nije jasno rečeno u kakvom su srodstvu Barzilaj i Kimham. Sigurno je riječ o članu Barzilajeve obitelji, a tradicija drži da je Kimham Barzilajev sin. ${ }^{11}$ U 1 Kr 2, 7 govori se o Barzilajevim sinovima, što se može odnositi i na njegovo potomstvo u bilo kojem koljenu. U svakom slu-

\footnotetext{
${ }^{10}$ Usp. S. GERJOLJ, Drame biblijskih obitelji, Split, 2015., 117-118.

${ }^{11}$ Tako primjerice Josip Flavije u Židovskim starinama (Ant. 7, 274-275) prepričava taj događaj tako da je sam David tražio od Barzilaja da pusti svoga sina Kimhama s njime u Jeruzalem, kako bi on mogao uživati ono što ne može njegov ostarjeli otac. Konzultirali smo tekst Židovskih starina na engleskom jeziku koji se može naći u programu Bible Works version 10.0.5559.
} 
čaju Barzilaj se ipak ne želi povući u svoj grad bez ikakva rezultata, a zna da David ne će odbiti njegovu molbu.

Prema tomu nakon što je izrazio nakanu da uredi svoje odnose s predcima, Barzilaj misli i na svoje potomstvo. Ako je Kimham njegov pravi sin, u ovoj sceni događa se takav oproštaj između oca i sina u kojem je otac istodobno pustio sina da se osamostali i pružio mu sigurnu budućnost. To je ideal koji bi mnoga djeca željela doživjeti od svojih roditelja. Uz to, predajući mu sina, Barzilaj je još jednom pokazao svoje povjerenje u kralja Davida, premda ovaj možda nije ispunio njegova očekivanja.

Susret Barzilaja i Davida završava dirljivim rastankom na rijeci Jordanu. David je poljubio i blagoslovio Barzilaja. Poljupcem se David ponizio i pokazao ljubav ${ }^{12}$ i poštovanje prema Barzilaju kao starijem čovjeku. Prema pravilu da veći blagoslivlja manjega (usp. Heb 7, 7) pokazao se kraljem koji je dobar prema svomu podaniku.

\section{Plodovi Barzilajeve lojalnosti kralju Davidu (1 Kr 2, 7)}

Pred kraj života kralj David, koji je sam postao tjelesno onemoćali starac (usp. $2 \mathrm{Kr}$ 1, 1-4), daje upute svomu nasljedniku, sinu Salomonu. Među ostalim nalaže mu kako će postupati prema različitim osobama koje su imale određenu ulogu u njegovu (Davidovu) životu. U 1 Kr 2, 5-9 spominju se tri takva lika: Joab, Šimej i, među njima, Barzilaj Gileađanin.

Situacija je slična onoj u 2 Sam 19, 19-40 kada Davidu na povratku u Jeruzalem pristupaju Šimej, Meribaal i Barzilaj. Šimej i Meribaal nisu se pokazali lojalnima Davidu, a Barzilaj je zbog svoje lojalnosti zaslužio nagradu. U 1 Kr 2, 5-9 susrećemo ponovno dva ista lika. Sada su to Šimej i Barzilaj, a umjesto Meribaala, sina Jonatana, kojemu se David zakleo da ne će uništiti njegovo potomstvo, nalazimo Joaba, sina Sarvijina, Davidova vojskovođu.

David govori sinu Salomonu o nečasnom Joabovu postupku kada je pogubio vojskovođe i Abnera i Amasa i upućuje ga da postupi tako da Joabova »sijeda glava ne počine mirno u podzemlju « $(1 \mathrm{Kr} 2,6)$. Salomon će kasnije doista postupiti tako da Joab bude pogubljen (1 Kr 2, 28-34). Šimeju, koji ga je proklinjao za vrijeme bijega pred Abšalomom, David je obećao da ga ne će pogubiti, ali to obećanje ne obvezuje njegova nasljednika Salomona, koji će i u tom slučaju naći načina da ispuni očev nalog (1 Kr 2,36-46).

${ }^{12}$ Zanimljivo je da je posljednja osoba koju je David poljubio prije te scene bio njegov sin Abšalom (2 Sam 14, 33), a Abšalom je, spremajući pobunu, pridobio simpatije naroda među ostalim i tako što bi poljubio svakoga tko bi mu se približio (2 Sam 15, 3). 
Između Davidovih uputa koje se odnose na uklanjanje Joaba i Šimeja Barzilaj Gileađanin se pojavljuje kao središnji i u tom društvu jedini pozitivni lik. ${ }^{13}$ David svom nasljedniku Salomonu govori kako će postupiti prema Barzilajevim potomcima:

»A sinovima Barzilaja Gileađanina vrati ljubav: neka budu među onima koji jedu za tvojim stolom jer su mi pomogli kad sam bježao pred tvojim bratom Abšalomom.« $(1 \mathrm{Kr} 2,7)$

Budući da David govori o Barzilajevim sinovima, a s obzirom i na to da je David već star, možemo zaključiti da je Barzilaj umro. Tako je za Barzilajevu lojalnost Davidu nagrađeno njegovo potomstvo, što pojačava dojam kako se isplati biti vjeran svomu kralju.

U knjigama o Kraljevima ne nalazimo druge podatake o Barzilajevim potomcima. Jedino prorok Jeremija spominje Kimhamovo svratište kraj Betlehema, pa je moguće da je tu riječ o Barzilajevu sinu Kimhamu koji je tu dobio posjed. ${ }^{14}$

Spomen Barzilajeva potomstva nadalje nalazimo u Knjigama o Ezri i Nehemiji. Riječ je o popisu povratnika iz babilonskoga sužanjstva koji nalazimo paralelno u Ezr 2, 61 i Neh 7, 63:

$\gg$ A od svećeničkih sinova: Hobajini sinovi, Hakosovi sinovi, sinovi Barzilaja - onoga koji je uzeo za ženu jednu kćer Barzilaja Gileađanina te se prozvao tim imenom.«

U nastavku se kaže da su sinovi toga Barzilaja isključeni iz svećenstva jer nisu mogli naći svoje rodoslovne popise kojima bi dokazali da pripadaju svećeničkoj lozi. No ovdje je važno da je spomenuti Barzilaj bio zet Barzilaja Gileađanina i da je pri ženidbi uzeo njegovo ime. Riječ je zapravo o tome da je muž uzeo prezime svoje žene, što je veoma izniman slučaj koji svjedoči o ugledu koji su Barzilaj Gileađanin i njegovi potomci imali u narodu.

\footnotetext{
${ }^{13}$ Raspored teksta u kojem je Barzilaj Gileđanin pozitivni središnji lik između dva negativna lika može se tumačiti kao uputa Salomonu da ukloni sve one koji sa svih strana mogu naškoditi njegovoj mirnoj vladavini, a nagradi one koji su mu lojalni. Usp. I. W. PROVAN, Why Barzillai of Gilead (1 Kongs 2:7)? Narrative Art and the Hermeneutics of Suspicion in 1 Kings 1 -2, u: Tyndale Bulletin 46(1995.)1, 103-116. Elektroničko izdanje: http://98.131.162.170/tynbul/library/ TynBull_1995_46_1_07_Provan_1Kgs2_Barzillai.pdf (20.11.2017.)

${ }^{14}$ Usp. R. D. BERGEN, 1, 2 Samuel, The New American Commentary, VII, Nashville, Tennessee, 1996., 432.
} 


\section{Lik Barzilaja u izvanbiblijskoj predaji}

Crkveni oci poput sv. Jeronima ${ }^{15}$ predstavljaju lik Barzilaja Gileađanina kao primjer razborita starca koji je svjestan što priliči, a što ne priliči njegovoj životnoj dobi. U jednoj od svojih poslanica (Ep. LII) sv. Augustinu, koju navodimo u starom prijevodu fra Ivana Markovića, sv. Jeronim kaže:

»I da bolje kažem sa svetim Pismom, onaj Galadjanin Berzelaj, prenoseći na mladog sina ljubav i slasti kralja Davida pokaza da stare godine takovih stvari nemaju željeti, ni primiti ih kad su im ponudjene.«

Tekstove koji predstavljaju Barzilaja kao uzornoga čovjeka, odanoga prijatelja, pomoćnika u potrebi, brižljiva oca i na koncu čovjeka svjesna svojih ljudskih ograničenja možemo i danas naći na raznim mrežnim stranicama biblijske i duhovne tematike. $^{16}$

Međutim židovska predaja pokazuje i neke druge crte njegova lika. U Židovskim legendama piše kako je David bio iznenađen Barzilajevom odanošću jer on inače nije bio čovjek visokoga moralnoga ponašanja. ${ }^{17}$ Srednjovjekovni rabin Salomon ben Izak, poznat po nadimku Raši, u svom komentaru na 2 Sam 19, 26 kaže: »naši učitelji tvrdili su da je on (Barzilaj) bio veoma promiskuitetan pa je zbog toga brzo ostario. $\ll{ }^{18}$

Potvrdu takvoga mišljenja nalazimo i u Babilonskom Talmudu (Šabat 152a):

$\gg$ Rav reče: 'Barzilaj Gileađanin jest lažac. Jer Rav je u svojoj kući imao slugu stara devedeset i dvije godine, koji je mogao kušati hranu. Rava je rekao: 'Barzilaj je upao u razvrat, a onaj tko upada u razvrat brže stari. Uči se da je R. Jišmael, sin R. Joseja rekao: 'što se tiče učenjaka, što su stariji to stječu više mudrosti, jer je rečeno Sjedine mudrost donose čovjeku, a s vijekom dugim umnost mu dolazi. (Job 12,12). A neznalice što su stariji to su luđi jer je rečeno On diže riječ iz usta rječitima i starcima pravo rasudivanje. (Job 12,20 ). ${ }^{19}$

${ }^{15}$ I. MARKOVIĆ, Izabrane poslanice sv. Jeronima, II, Zagreb, 1908., 152.

${ }^{16} \mathrm{Npr}$. https://www.biblegateway.com/resources/all-men-bible/Barzillai; https://www.gotquestions.org/Barzillai-in-the-Bible.html; http://www.bible.ca/ef/topical-barzillai.htm. (30. 11. 2017.)

${ }^{17}$ Usp. http://www.sacred-texts.com/jud/loj/loj405.htm (30. 11. 2017.)

${ }^{18}$ Prijevod prema engleskom tekstu koji se nalazi na mrežnoj stranici http://www.chabad.org/library/ bible (20. 11. 2017.). Raši na istom mjestu tumači Barzilajevu nemoć razlikovanja između dobra i zla u smislu da nije mogao razlikovati između dobre i loše hrane.

${ }^{19}$ Prijevod na temelju engleskoga teksta koji se nalazi na mrežnoj stranici http://come-and-hear. com/shabbath/shabbath_152.html\#152a_26, (30.11. 2017.) Biblijski citati Job 12, 12.20 preuzeti su iz hrvatskoga prijevoda u izdanju Kršćanske sadašnjosti. 
Navedeni primjeri navode na zaključak kako Barzilajeva tjelesna nemoć u osamdesetoj godini ne mora biti neizbježna oznaka njegove staračke dobi, nego je plod njegova neuredna života. U svjetlu te izvanbiblijske tradicije biblijski lik Barzilaja Gileađanina možemo potpunije sagledati i izvući neke zaključke koje bi nam u golim biblijskim tekstovima ostali sakriveni.

\section{Zaključak}

Promatranjem lika Barzilaja Gileađanina na temelju biblijskih i nekoliko izvanbiblijskih tekstova otkrivamo slojevitu sliku čovjeka koji se nalazi u posljednjim godinama života. Ukupno su u Bibliji iz Barzilajeva života ispričane samo dvije povezane epizode u kojima su u prvom planu predstavljene pozitivne crte njegova lika. On je ugledan i imućan čovjek koji u vrijeme Abšalomove pobune ostaje odan njegovu ocu i svojemu kralju Davidu. Barzilaj pomaže Davidu u potrebi, a kad je nevolja prošla, izlazi mu u susret da ga isprati na pobjedničkom putu prema Jeruzalemu. Uz to, kada mu David želi pokazati svoju zahvalnost, Barzilaj ponuđenu nagradu prepušta svomu sinu Kimhamu i tako ostavlja dojam skromnoga čovjeka i brižnoga oca. Ostali biblijski tekstovi svjedoče o tome kako je njegova lojalnost Davidu urodila dobrim plodom za njegovo potomstvo, a sam Barzilaj ostao je u biblijskoj povijesti zapamćen kao pozitivan lik.

Pa ipak, već između redaka mogu se u dvjema biblijskim epizodama iz Barzilajeve poodmakle dobi nazrijeti elementi koji nose tragove njegova prijašnjega života. Njegove izjave kako u svojim godinama više ne može uživati u užitcima koji se nude na kraljevskom dvoru formulirane su tako da možemo zaključiti kako ga u tom ne sprječavaju moralne ograde, nego tegobe starosti. Uz to odbijanje baš takve nagrade koju mu nudi kralj David ne isključuje mogućnost da je Barzilaj očekivao neku drugu nagradu. Umjesto uzdržavanja do smrti, što mu kao imućnom čovjeku nije bilo ni potrebno, možda je Barzilaj priželjkivao mjesto među Davidovim savjetnicima. Kada to nije dobio, odlučio se vratiti u svoj grad gdje je uživao status uglednika. O tome, naravno, možemo samo nagađati.

Međutim nekoliko izvanbiblijskih tekstova svjedoči o tome kako Barzilaj u židovskoj tradiciji nije ostao zapamćen samo po svojoj lojalnosti Davidu i po tome što se zahvalio na nagradi za svoje dobro djelo. O Barzilaju se govori i kao o čovjeku koji nije živio na moralnoj visini.

Što možemo zaključiti i kakvu poruku prepoznati kada povežemo biblijsku i izvanbiblijsku sliku o Barzilaju?

Biblija prikazuje Barzilaja u pozitivnom svjetlu, ali nam ništa ne govori o njegovu životu prije dvaju susreta s Davidom. Povežemo li to s izvanbiblijskom tradicijom 
koja ga s moralne točke gledišta predstavlja u negativnom svjetlu, onda posljednji susret Barzilaja i Davida možemo promatrati kao svojevrsnu prekretnicu u Barzilajevu životu.

U susretu s Davidom Barzilaj izražava svijest o tome da mu nije preostalo još mnogo godina života. Ali možda ga je svojom ponudom da će ga u njegovim starim danima uzdržavati na kraljevskom dvoru upravo David osvijestio s obzirom na njegovu životnu dob.

U svakom slučaju, Barzilaj uviđa da zbog svoje starosti na kraljevu dvoru ne može živjeti na način koji bi prema izvanbiblijskoj tradiciji odgovarao njegovu dotadašnjem životnom stilu.

A isto tako on ne želi na kraljevu dvoru biti uzdržavan kao starac koji samo čeka trenutak smrti.

Kada pozitivne Barzilajeve crte koje predstavljaju biblijski tekstovi povežemo s izvanbiblijskom tradicijom koja ga ne pamti kao čovjeka uzorna života, dobivamo sliku Barzilaja kao čovjeka koji barem na zalasku svoga zemaljskoga života želi postupiti ispravno. Susret s Davidom koju mu je ponudio lijepu, ali njemu neprikladnu nagradu, postao je prigoda u kojoj je Barzilaj odlučio učiniti ono što može i što mu se čini najvažnijim u njegovoj životnoj dobi. Odlučio je urediti odnose sa svojim najbližima. Poželio je mirno umrijeti kod groba svojih roditelja, a svome potomstvu, koje će sačuvati njegovo ime, osigurati sigurnu i časnu budućnost. $U$ tome je i uspio.

Svojim primjerom pokazao je kako je i staračka dob vrijeme u kojem su čovjeku otvorene mogućnosti da čini dobro. To se odnosi i na to da je u starosti moguća pozitivna promjena u moralnom i duhovnom životu. Premda Barzilaj prema izvanbiblijskoj tradiciji nije bio moralno uzoran čovjek, ista tradicija u talmudskim Izrekama otaca $(1,6)$ donosi načelo: »Sudi čovjeka prema njegovoj boljoj strani. $\ll^{20}$ Poštivanje toga načela možemo prepoznati upravo u navedenim biblijskim tekstovima o Barzilaju koji je u svojoj starosti pokazao svoju dobru stranu.

${ }^{20}$ E. WERBER (prev.), Talmud. Izbor i prijevod tekstova s hebrejskoga i aramejskoga, povijest Talmuda i bilješke napisao Eugen Werber, 1. izdanje Otokar Keršovani, Rijeka, 1982. Reprint izdanje Litteris, Zagreb, 2008., 144. 


\section{THE ATTITUDE OF BARZILLAI THE GILEADITE TOWARDS HIS OLD AGE}

\section{Domagoj RUNJE*}

Summary: The figure of Barzillai appears several times in the biblical texts and the two most important are 2 Sam 17:27-29, where Barzillai helps King David during the escape from his son Absalom who rebelled, and 2 Sam 19:32-40, where Barzillai meets King David again and speaks about his old age. This text is the focus of this paper where we observe Barzillai's attitude towards his old age. There is also mention of several other texts from Jewish non-biblical tradition that help us better understand this biblical figure.

Keywords: Barzillai, King David, old age, Bible, Talmud.

\footnotetext{
* Asst. Prof. Domagoj Runje, Ph. D., Catholic Faculty of Theology, University of Split, 21000 Split, Croatia, drunje2@kbf-st.hr
} 